\title{
Novel use of pop-up satellite archival telemetry in sawsharks: insights into the movement of the common sawshark Pristiophorus cirratus (Pristiophoridae)
}

\author{
Patrick J. Burke ${ }^{1 *}$ (D), Johann Mourier ${ }^{1,2}$, Troy F. Gaston $^{3}$ and Jane E. Williamson ${ }^{1,4}$
}

\begin{abstract}
Background: Understanding movement patterns of a species is vital for optimising conservation and management strategies. This information is often difficult to obtain in the marine realm for species that regularly occur at depth. The common sawshark (Pristiophorus cirratus) is a small, benthic-associated elasmobranch species that occurs from shallow to deep-sea environments. No information is known regarding its movement ecology. Despite this, P. cirrata are still regularly landed as nontargeted catch in the south eastern Australian fisheries. Three individuals were tagged with pop-up satellite archival tags (PSATs) off the coast of Tasmania, Australia, to test the viability of satellite tagging on these small elasmobranchs and to provide novel insights into their movement.
\end{abstract}

Results: Tags were successfully retained for up to 3 weeks, but movement differed on an individual basis. All three individuals displayed a post-release response to tagging and limited vertical movement was observed for up to 5-7 days post-tagging. Temperature loggers on the tags suggest the animals were not stationary but moved horizontally during this time, presumably in a flight response. After this response, continuous wavelet transformations identified diel vertical movements in one individual at cyclical intervals of 12- and 24-hour periods; however, two others did not display as clear a pattern. Temperature was not significantly correlated with movement in the study period. The deepest depths recorded during the deployments for all individuals was approximately $120 \mathrm{~m}$ and the shallowest was $5 \mathrm{~m}$.

Conclusions: This study demonstrates that sawsharks can be successfully tagged by pop-up satellite archival tags. The data presented here show that sawsharks regularly move both horizontally and vertically in the water column, which was an unexpected result for this small benthic species. Additional research aimed at resolving the trophic ecology will help identify the drivers of these movements and help to better define the ecological, behavioural and physiological roles of these sharks in their ecosystems. These data describe a substantial ability to move in the common sawshark that was previously unknown and provides the first account of movement ecology on the family of sawsharks: Pristiophoridae.

Keywords: Elasmobranch, Satellite telemetry, Diel vertical migration, Tagging, Pristiophoridae, Australia, Movement

${ }^{*}$ Correspondence: Patrick-john.burke@hdr.mq.edu.au

1 Department of Biological Sciences, Macquarie University, Sydney, NSW 2109, Australia

Full list of author information is available at the end of the article

\section{Background}

Organisms in the deep-sea biome present various environmental challenges for study even with the most technologically advanced equipment [1]. Despite a lack of biological information for many deep-sea

c) The Author(s) 2020. This article is licensed under a Creative Commons Attribution 4.0 International License, which permits use, sharing, adaptation, distribution and reproduction in any medium or format, as long as you give appropriate credit to the original author(s) and the source, provide a link to the Creative Commons licence, and indicate if changes were made. The images or other third party material in this article are included in the article's Creative Commons licence, unless indicated otherwise in a credit line to the material. If material is not included in the article's Creative Commons licence and your intended use is not permitted by statutory regulation or exceeds the permitted use, you will need to obtain permission directly from the copyright holder. To view a copy of this licence, visit http://creativeco mmons.org/licenses/by/4.0/. The Creative Commons Public Domain Dedication waiver (http://creativecommons.org/publicdomain/ zero/1.0/) applies to the data made available in this article, unless otherwise stated in a credit line to the data. 
inhabitants, habitat within the deep-sea biome are increasingly targeted for harvest by expanding fisheries $[2,3]$. Deep-sea sharks (species that predominantly occur below $200 \mathrm{~m}$ ) remain one of the more poorly understood group of elasmobranchs but continue to be regularly caught in fisheries $[4,5]$. In areas where deepsea sharks are targeted, dramatic population declines have been observed $[5,6]$. The impacts of harvesting such species are usually unknown but may have long lasting consequences because of the low productivity and low intrinsic rebound potential observed in many deep-sea chondrichthyans [4].

Sharks play a crucial role in ecosystem functioning and stability [7-9]. Many species perform critical roles in structuring biological communities through predation by exhibiting top-down controls thus allowing lower trophic levels to maintain viable diversity $[10,11]$. As such, the presence, abundance and health of such predators have been used as indicators of the overall health of ecosystems $[10,12,13]$. In addition, indirect effects of predators can be observed through prey response to the predators [14]. Such effects involve prey actively avoiding certain areas or habitats associated with sharks or high shark abundance [14, 15]. These result in increased time and energy spent on predator avoidance, which could impact the fitness of prey species [16]. Consequently, these effects substantially influence species and communities throughout the predator's distribution.

Sawsharks (Pristiophoridae) share many of the typical characteristics of deep-sea sharks and are also relatively understudied [4, 17]. Most of the information known about this group is derived from fisheries-dependent sources [18-22]. These data often lack location of fishing grounds, species-specific information for nontarget catch, and inherent bias introduced by a commercially driven fleet [23]. As such, the true demographics and population structure of these animals are generally unknown [4]. This is problematic as many populations are continually fished. Undoubtedly, fisheries management needs a broad understanding of species-specific information to make informed decisions on management strategies [24].

The common sawshark Pristiophorus cirratus (Latham, 1794) is a small, benthic-associated shark endemic to south eastern Australia and occurs from shallow to deepsea environments [25]. Very little information is known about this species and what is known is primarily from recent studies relating to aspects of their diet [26], longevity concerns [27], and biological features [28, 29]. These animals are a regular facet of nontarget catch in the trawl, gillnet, and Danish-seine fisheries of south eastern Australia [19] and despite over 90 years of continued fishing there remains a dearth of biological data on P. cirratus, particularly in movement ecology.

Understanding animal movement is key if meaningful management and conservation efforts are to be effectively employed [30]. The scope of an animal's ability to disperse influences population dynamics, nutrient distribution, productivity, resilience and other ecosystem level processes [31]. For example, the first marine protected area located entirely in the high seas was partially justified by movements of the Adélie penguins (Pygoscelis adeliae) during their energy-intensive premoult period [32]. Furthermore, many human activities pose serious threats to the ecology of marine life [33, 34]. Examples include increased fishing pressure $[35,36]$, pollution $[37,38]$ and oil and gas extraction or exploration [39, 40]. Knowledge of movement patterns can provide data essential for the identification and mitigation of potential impacts [31]. Until recently, collecting this information for small deep-sea sharks was very challenging [41]. However, miniaturization of satellite telemetry tags and their ability to record location and abiotic factors has made such data collection more feasible for these species, including smaller bodied sharks [41]. In this study, we tested the efficacy of pop-up satellite archival tags on the common sawshark as an initial assessment into the applicability of using such tags for tracking movement of smaller deep-sea sharks, and to assess short-term movement in relation to depth for this sawshark species. This study provides the first baseline data on movement ecology from satellite tagging for any Pristiophorid species.

\section{Results}

Three PSATS were deployed and all three sawsharks swam away strongly on release. Tag retention durations were 14 days (Tags 167263 and 167264) and 23 days (Tag 167262) (Table 1). The percent of archived data successfully transmitted to the ARGOS satellite network was 64\% for tag 167262 and 93\% for tag 167264. Tag 167263 was recovered, allowing the entire uncompressed dataset to be downloaded. Initial deployment location with the date and location of first transmission paired with corresponding depth profiles and bathymetry were used to indicate a rough path of movement (Fig. 1). The data did not allow for traditional light-based geolocation methods given limitations imposed by tag type (Tag 167264) and by failures in light level data collection (Tags 167262 and 167263).

\section{Horizontal movements}

Data from all three tags suggest a southward movement after release using first transmission location in relation to deployment location (Fig. 1). Variability in temperature data was used as a proxy to estimate that the 


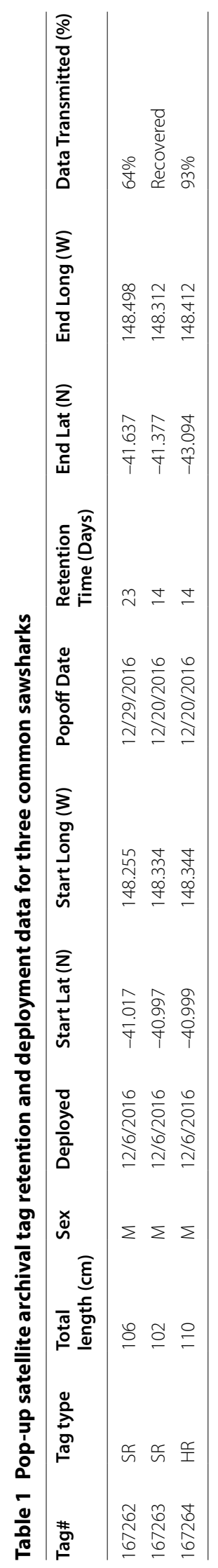




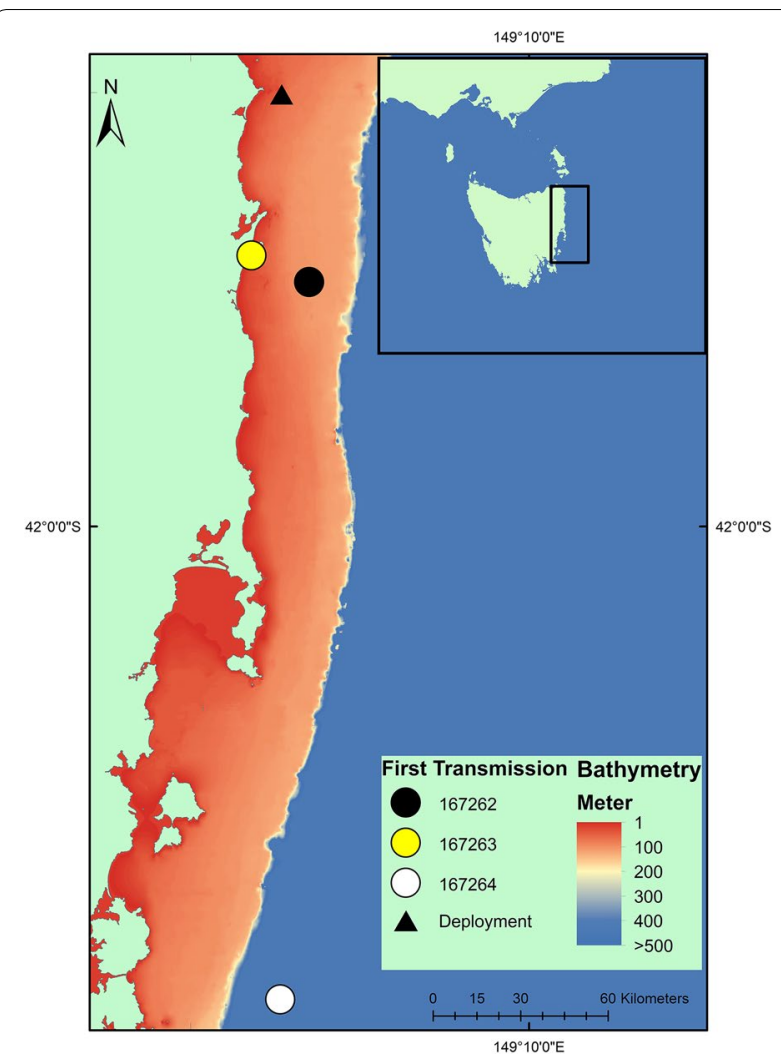

Fig. 1 Bathymetric map depicting the tagging location (black triangle) and initial satellite transmission locations (circles). Tag 167264 was at drift for $\sim 15$ days before making first transmission shark was not stationary but likely moving horizontally. Tag 167262 displayed conservative minimum horizontal movement of approximately $70 \mathrm{~km}$ from tagging to release in the 23-day deployment period. Tag 167263 was recovered approximately $60 \mathrm{~km}$ from the tagging location after being attached to the animal for a 14-day deployment period. Tag 167264 was drifting at the surface for a period of approximately 15 days after release before it successfully transmitted to the satellite network. Due to this substantial time period and considerable variability in currents in this area horizontal movements were not estimated for this individual.

\section{Diurnal structure of movement}

Data from tagged sawsharks displayed similar postrelease vertical activity patterns with variable diurnal correlations. All sharks showed very little vertical movement in the immediate days following release during their "southward movement stage" (see above), and the duration of this first period varied between the three sharks (Fig. 2). Archived data from the sawshark bridled with tag 167262 suggested a post-release period of limited vertical activity for approximately 5 days upon which it began regular vertical movement patterns (Fig. 2a). The mean depth of the shark's position was significantly different between day and night $(\mathrm{F}(1,529)=42.42, p=1.71 \mathrm{e}-10)$. Data from tag 167263 also illustrated a limited vertical movement period of approximately 5 days and a switch to regular vertical forays (Fig. 2b). Mean depth was significantly different between day and night $(\mathrm{F}(1,347)=15.39$, $p=0.0001$ ). Archived data from 167264 displayed more variable vertical activity (Fig. 2c). Vertical movements were limited for approximately 3 days after release and then began an erratic period of approximately 2 days of continuous vertical movements throughout the water column. The mean depth during this second period was not significantly different between day and night ( $F$ $(1,172)=1.122, p=0.291)$.

Periodicity of vertical movements were explored further through the use of continuous wavelet transformations (CWTs). Data from tag 167262 exhibited diel patterns of movement in a cyclical pattern of approximately 12- and 24-hour periods (Fig. 3a). Data from tag 167263 exhibited cyclical patterns in the middle of the deployment at approximately 12- and 24-hour periods (Fig. 3b). Lastly, data from tag 167264 displayed no apparent temporal or cyclical pattern of vertical activity during deployment (Fig. 3c). Cyclical patterns were discerned through high amplitude bands or peaks in red with statistically significant patterns encircled in white $(p<0.1)$ and black lines representing periods of the strongest statistical patterns $(p<0.05)$.

\section{Benthic movements}

The proportion of deployment time spent on the benthos vs non-benthos varied between the three sharks. The individual with tag 167262 spent $86.9 \%$ on the benthos and $13.1 \%$ off the benthos (Fig. 4 a). $1.7 \%$ of the off-benthos movements were conducted during the day and 98.3 during the night. The individual with tag 167263 spent $96.3 \%$ on the benthos and $3.7 \%$ off the benthos (Fig. 4b) with $11.1 \%$ of the off benthos movements occurring during the day and $88.9 \%$ at night. The individual with tag 167264 spent $95.1 \%$ on the benthos and $4.9 \%$ off the benthos (Fig. 4c) with $36 \%$ of the off benthos movements occurring during the day and $64 \%$ at night.

\section{Water column movements}

The tag data suggests the three sharks used the water column in differing capacities (Fig. 5). Tag data from 167262 had a mean $( \pm S D)$ depth of $87.8 \mathrm{~m} \pm 20.8 \mathrm{~m}$ (Fig. 5a). Tag data from 167263 had a mean $( \pm$ SD) depth of $68.3 \mathrm{~m} \pm 6.8 \mathrm{~m}$ (Fig. 5b). Tag data from $167264 \mathrm{had}$ a mean $( \pm$ SD) depth of $76.1 \mathrm{~m} \pm 25.8 \mathrm{~m}$ (Fig. $5 \mathrm{c}$ ). 

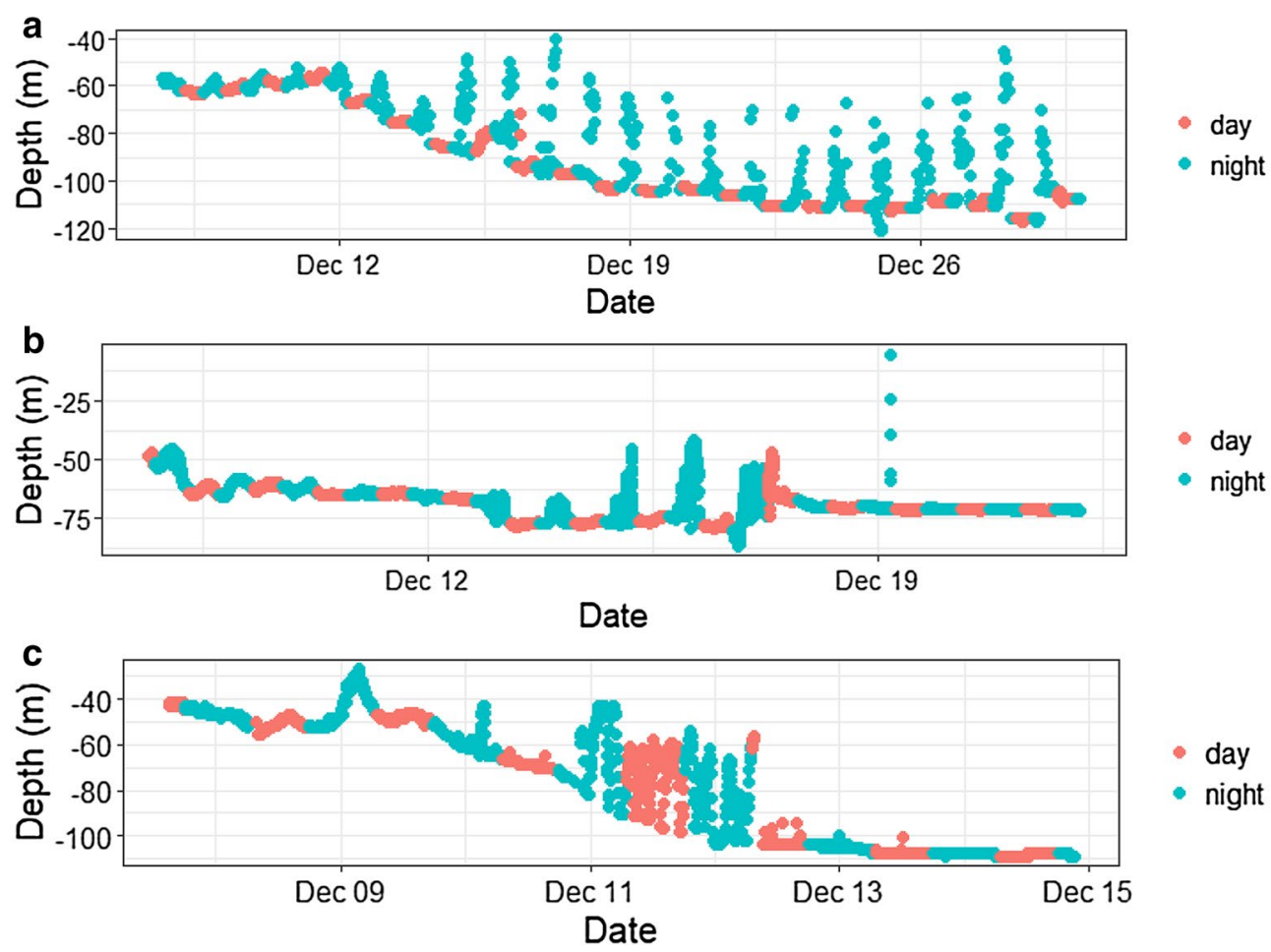

Fig. 2 Water column movements of common sawsharks from pop-up satellite archival tags in relation to time of day. a Tag 167262, b Tag 167263, c 167264. Note the differences in the $y$-axis

\section{Discussion}

This study provides first insights into the movement ecology and novel use of pop-up satellite archival tags in any member of the sawshark family. While the low sample size represented in this study limits our conclusions on a broader scale, it provides evidence for previously undescribed vertical behaviour of the common sawshark, initial insights into horizontal movements, and the applicability of PSAT technology in sawsharks.

Success of long-term retainment of PSATs in sawsharks could be improved. This study used the dorsal bridle attachment method, a common technique in shark tagging studies [42]. However, it is possible that the fin tissue of sawsharks is not robust enough to ensure long-term retainment of tags in this manner. Future studies could explore muscle-based attachment methods. Two such methods that have seen success in teleosts and small elasmobranchs are a dorsal musculature-based bridle [43] and steel dart anchors implanted into the muscle tissue [44]. We suggest future studies explore musculature-based attachment techniques to ensure long-term retainment.

The tagged sawsharks moved considerable distances during deployment of the tags. The first transmission date of the tags when paired with archived tag data allowed us to ascertain a conservative distance of animal movement over time. This estimate displayed a minimum movement of $70 \mathrm{~km}$ in 3 weeks, or $3 \mathrm{~km} \mathrm{day}{ }^{-1}$ in one individual. Previous research on other small benthic sharks, such as the Port Jackson shark Heterodontus portusjacksoni, found rates of movement around $1.8 \mathrm{~km} \mathrm{day}^{-1}$ [45] and $6.5 \mathrm{~km} \mathrm{day}^{-1}$ [46]. Furthermore, a recent study investigating long-term migrations of Port Jackson sharks found that they can move up to $19.5 \mathrm{~km} \mathrm{day}^{-1}$ and move distances greater than $600 \mathrm{~km}$ in migratory events [47]. Therefore, future research into sawsharks should aim to monitor individuals for evidence of philopatry or migratory events with a longer term tracking study.

Diel vertical movement is a common phenomenon observed across a broad range of marine taxa [44, 4854]. A number of shark species display diel vertical movements correlated to ascension at night and a return to depth at day [55-59]. Our data suggest that sawsharks may employ a similar pattern of movement. One of our tagged individuals displayed regular vertical movements in the water column by ascending during the night in approximately 12- and 24-hour cyclical patterns and returning to what we assume is the sea floor during the day. Similar diel movements were observed in another individual. However, the third individual displayed a very different vertical pattern of movement. Diel mediated vertical movement patterns are common in large 

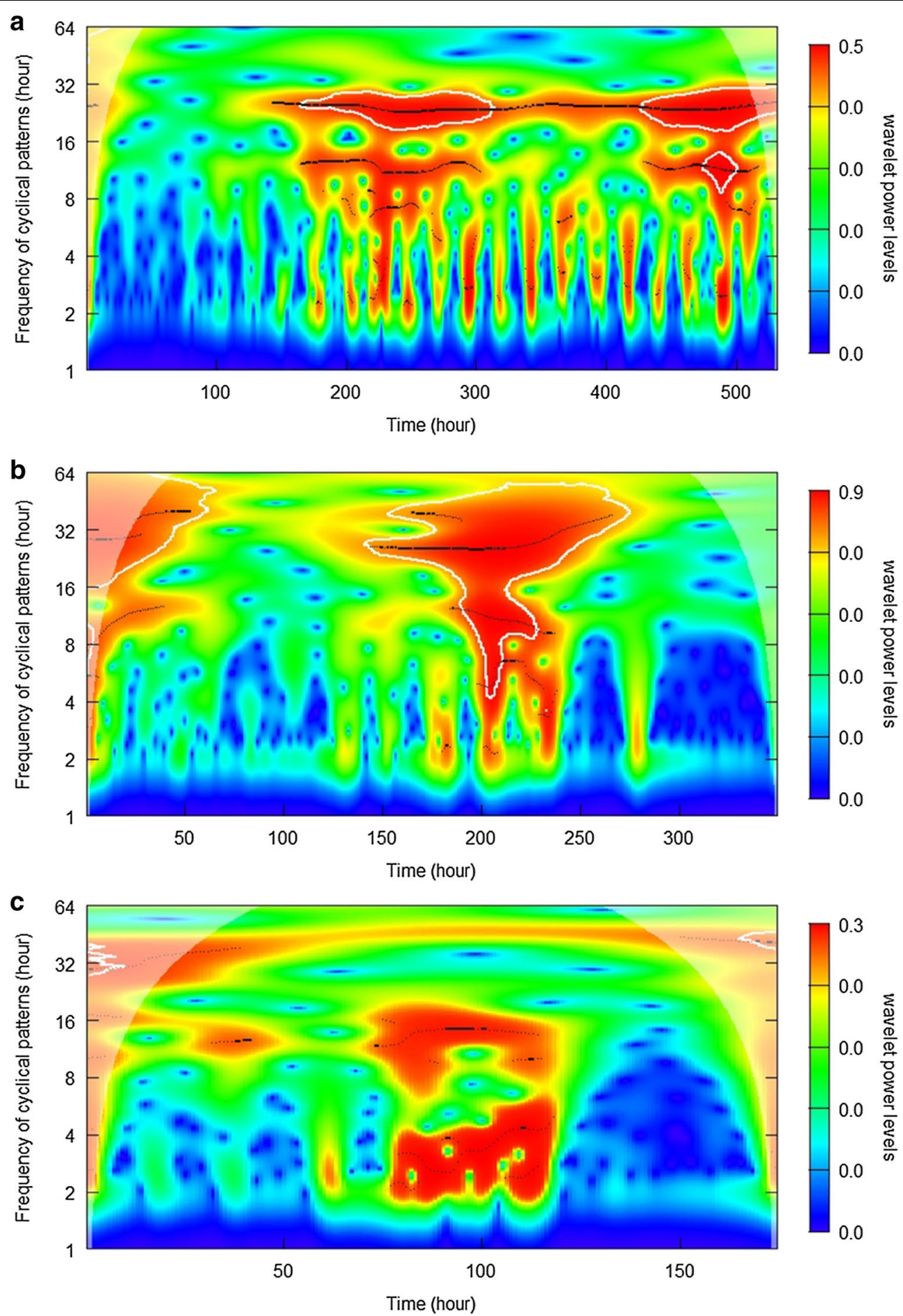

Fig. 3 Continuous wavelet transformations (CWTs) for vertical movement of three sawsharks tagged with PSATs a Tag 167262, b Tag 167263, c Tag 167264. The $x$-axis represents total hours post-tagging and the $y$-axis shows frequency of cyclical patterns in hours. Patterns outside the cone of influence should not be interpreted. Areas circled with white lines represent statistically significant patterns of periodicity of vertical movements at a significance of $p<0.1$ and the black lines represent statistically significant patterns of periodicity of vertical movements at $p<0.05$. Wavelet power levels indicate the strength of patterns observed across the period analysed. Note the change in the $x$-axis and colour ramp 


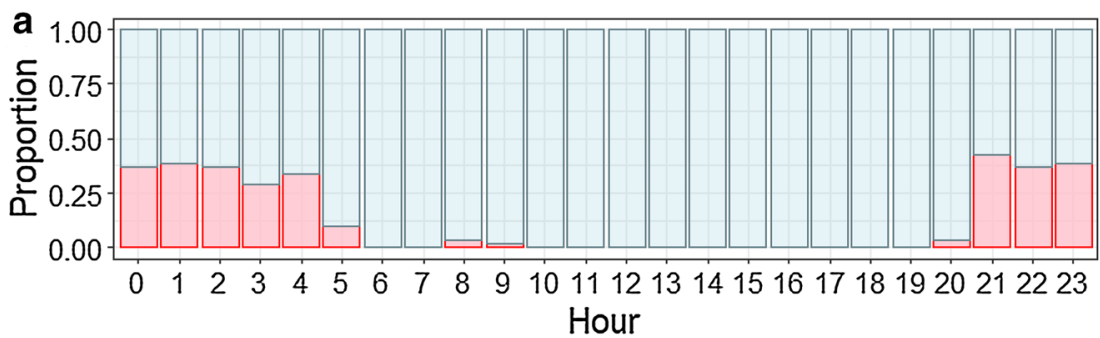

benthos

nonbenthos

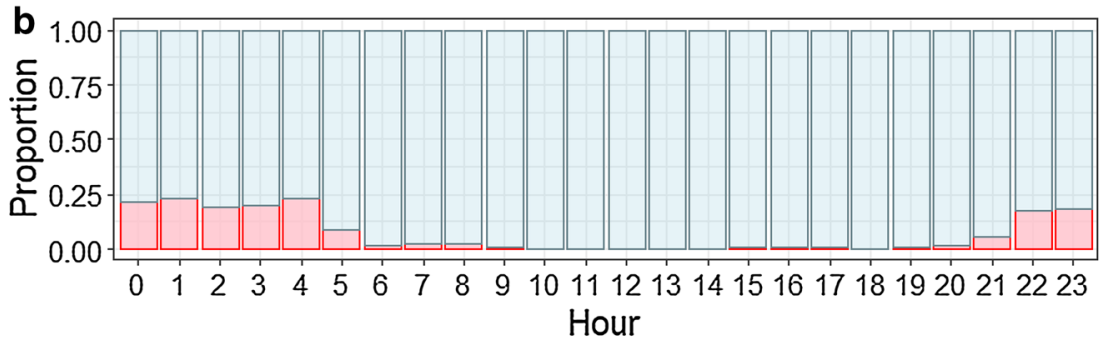

benthos

nonbenthos

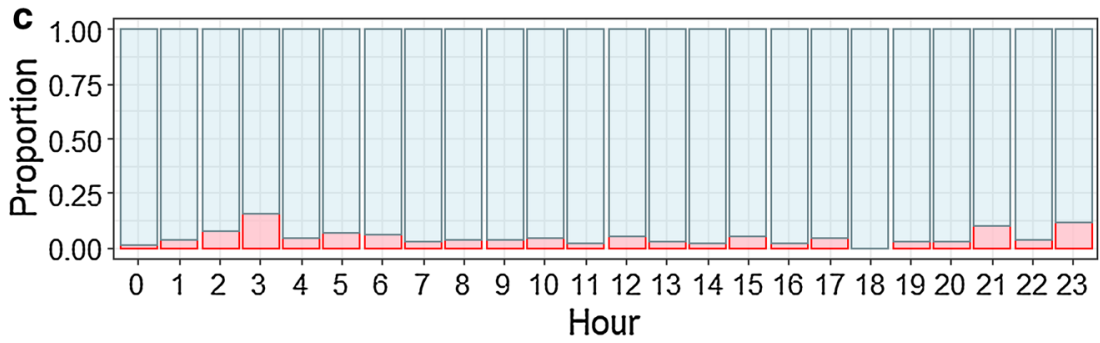

benthos

nonbenthos

Fig. 4 Proportion of benthos vs non-benthos positioning by hour of the day throughout deployment
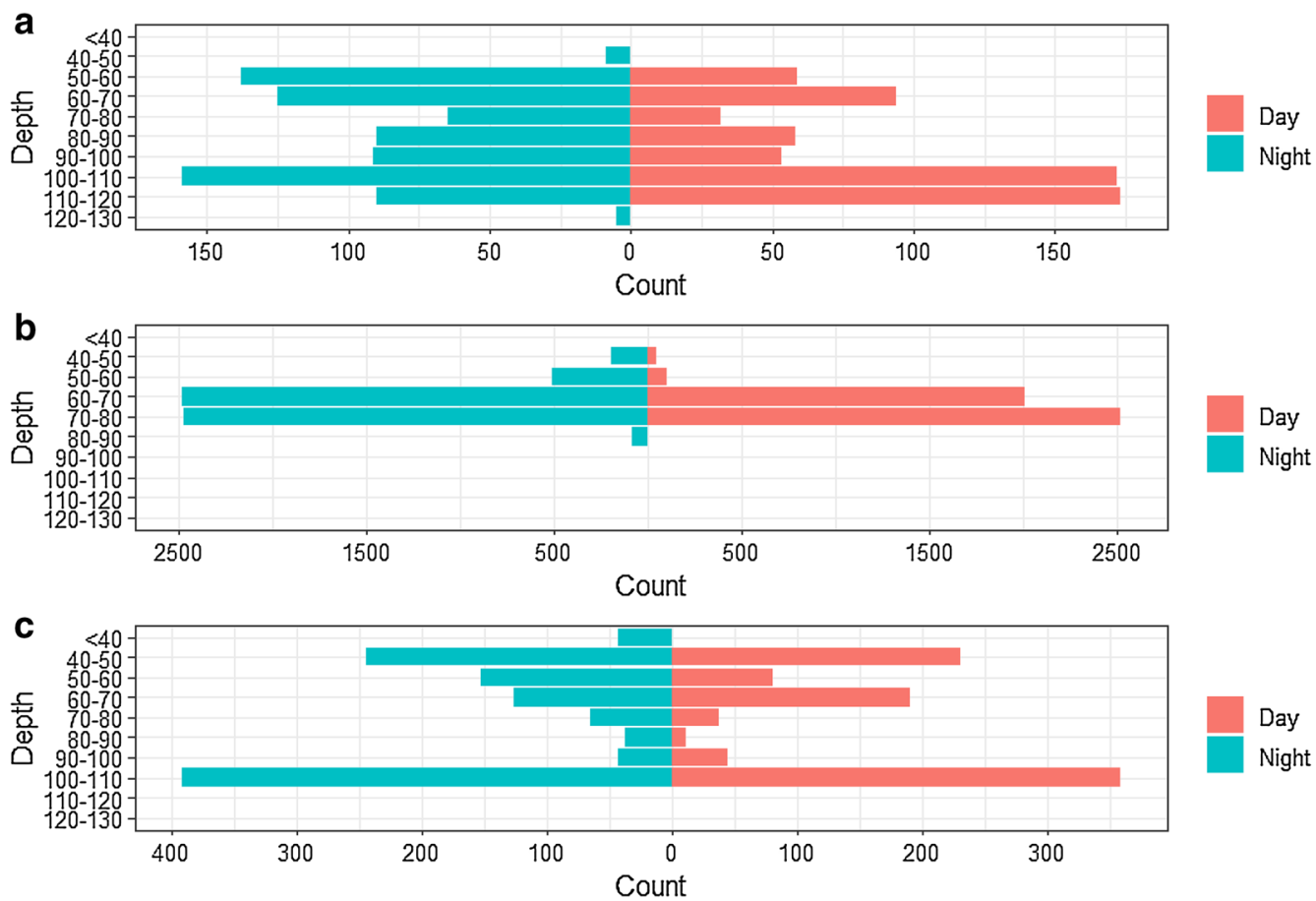

Fig. 5 Distribution of sawsharks' diurnal vertical water column use from pop-up satellite archival tags. Red delineating day and blue night. a Tag 167262, b Tag 167263, c Tag 167264 
epipelagic fishes [52, 53]; however, this phenomena is not well documented in small, benthic-associated fishes [48]. Current literature suggests common sawsharks feed primarily on benthic primary consumers [26, 29], so it is plausible that the observed vertical movements are predatory events following the well documented diel movements of primary consumers [60-62]. Furthermore, similar 'yo-yo' vertical movements, where the animal makes regular rapid vertical ascents then descents have been linked in other shark species for prey detection [53]. Our present dataset, however, is lacking the resolution and replication required to unequivocally link a driving factor for such movement and should be a focus of future research for sawsharks.

The behavioural changes observed in our tagged individuals post-release suggested a potential impact of the tagging event on the behaviour on the sawsharks. All individuals displayed limited vertical movement and a progressive movement towards deeper water during the immediate post-tagging period, potentially as a postrelease response to capture. Presumably, this could be a defence mechanism, where moving to deeper waters may provide increased protection against visual predators potentially due to lower light levels $[52,63]$. This response may also be related to behavioural, physiological and biochemical changes such as those observed in a range of species in relation to capture induced stress [64-67]. These include blood chemistry parameters such as lactate or $\mathrm{pH}$, which have been correlated to irregular behaviour and even to moribund fish [51, 68, 69]. Furthermore, these effects have been observed to have lasting sublethal effects that may affect the fitness of released fish $[65,66]$. Capture induced stress and subsequent effects are species specific and are likely to be mediated by basic biological functions, allowing for better adaptions to capture (i.e., buccal pumping allowing for oxygenation when movement is limited [70]). However, it is still unclear what effect fishing has on the physiology on sawsharks and their resilience to capture and subsequent release. Areas of future study could include monitoring and comparison of blood physiology parameters under different fishing techniques to allow a better understanding of technique specific responses, which could then allow for better understanding of survivability post-release.

Two out of three sharks displayed a notable cessation of vertical movement prior to the detachment of the tag. It is possible these were mortality events, which could be from either predation or post-release complications of tagging. Mortality events are an inherent risk of studying sharks that first must be captured for tags to be fitted. One study, using a risk assessment based approach, estimated that sawsharks in the gillnet fisheries have an approximate $50 \%$ mortality rate post-release, thought to be due to physical damage received in the gillnet [71] Mitigation of capture stress to promote survivability of fish post-tagging has seen increasing attention [41, 72]. Novel techniques such as releasing tagged sharks in cages, where the door is pressure released on reaching the seabed has seen some success by providing animals shelter from predation while they recover [41]. However, our current understanding of sawshark biology and ecology is lacking the fundamental information to understand the main drivers of stress and eventual mortality in released sawsharks.

\section{Conclusions}

Consistent decreases in sawshark landings across all south eastern Australian fisheries have recently been observed [19]. With only eclectic information on the biology or ecology of sawsharks, the impacts of increased fishing pressure in deeper waters remain unknown for these species. Contemporary literature has called for research into their movement and genetics to better understand population structure and, therefore, resilience to fishing pressure locally and at a species level. Though the data in this study are limited to three individuals, this pilot study lends insight into previously unknown sawshark movement and serves as a model to build on for future sawshark telemetry studies. Due to the limited replication and temporal scope of this research, broad conclusions on sawshark movement cannot be conclusively made. Our data provide documentation, however, of considerable distance travelled, water column use, and an undescribed diel vertical movement for this species. Given these data presented here, we suggest that more comprehensive tagging studies are warranted to better understand the ecology of these poorly understood sharks.

\section{Methods}

Sawsharks were caught and tagged off the northeast coast of Tasmania, Australia (40.99 S, 148. 33 E) during a research cruise in December 2016 on the FTV Bluefin. A series of short, deep trawls between $60 \mathrm{~m}$ and $100 \mathrm{~m}$ using a $70 \mathrm{~mm}$ mesh demersal fish net were conducted for $30 \mathrm{~min}$ at a speed of approximately 3.1 knots $(\mathrm{kn}, 1$ knot $=\sim 0.5144 \mathrm{~m} \mathrm{~s}^{-1}$ ) in an effort to reduce stress on the sharks by reducing the time spent in the net. Common sawsharks $(n=3)$ were tagged with two types of pop-up satellite archival tags (PSATs): X-Tags (Standard Rate [SR, $n=2]$ and High Rate [HR, $n=1$ ], Microwave Telemetry, Inc., Columbia, MD, USA) (Table 1).

Data on temperature, pressure (depth), and light levels (geolocation) throughout the preprogramed deployment period were collected by the X-Tags. Due to satellite 
throughput limitations, entire datasets are not automatically transmitted by the tag. Instead, a smaller subset, the 'transmitted' dataset, generated by a series of compressions applied to the archived dataset is sent to the satellites, depending on tag deployment programming chosen. In our research, the two SR tags compressed and transmitted data in 15 min records, while the HR tag compressed and transmitted data in 5 min records.

On capture, individuals were measured (total length, $\mathrm{TL})$ to the nearest centimetre, sexed, assessed for vitality and immediately tagged with a pop-up satellite archival tag (PSAT) to the dorsal fin via a bridal method. Only vital individuals with no sign of capture damage or exhaustion were used and the study was limited to males to eliminate any sex-specific movement. The bridal method involved piercing a small hole at the base of the dorsal fin then threading through a $10 \mathrm{~cm}$ length of monofilament attached to the PSAT and securing via a crimp. This method has been successful in securing similar tags in a range of other sharks and was advised by the tag manufacturers [41].

Tagged individuals were placed in a holding tank $(1 \mathrm{~m} \times 2.5 \mathrm{~m} \times 0.75 \mathrm{~m})$ on the deck of the vessel to recover and then released. Recovery was identified as when an individual was swimming normally irrespective of the tag (Williamson, personal observation). As retention time of the tags on sawsharks was unknown, each of the three tags was programmed to compress data at different time internals to maximise the opportunity of ecologically important data retrieval. PSATs were thus programmed to release at 30 [HR tag 167264], 60 and 90 [SR tags 167262, 167263] days, respectively.

\section{Data analysis}

All tag data were explored, plotted, and analysed using R Studio (ver. 3.3.0, R Foundation for Statistical Computing, Vienna, Austria) and ArcGIS (ESRI, ArcMap 10.6). Data were binned hourly, standardised for sunrise and sunset and then delineated into day (6:00-20:59) and night (21:00-5:59) based on natural diel patterns of deployment duration. Data on mean depth of day and night positions by hour were analysed using ANOVAs.

Periodicity in vertical movements were investigated using Continuous Wavelet Transformations (CWTs). CWTs (Morlet wavelet) identify dominant cyclical signals in time series datasets and display a frequency of how they change through time [73] and these analyses are particularly suited for temporal autocorrelation patterns [74]. In essence, CWTs are capable of interpreting multi-scale, non-stationary time series data and reveal features we may not see otherwise [75]. The mean depths for each hour of the entire deployment were determined and CWTs were produced on these data using a Morlet wavelet in the
waveletComp package [76] in R Studio. CWTs were calculated using the following parameters: loess $\operatorname{span}=0, \mathrm{dt}=1$, $\mathrm{dj}=1 / 250$, lowerPeriod $=1$, upperPeriod $=64, \mathrm{n} \cdot \operatorname{sim}=100$, see Roesch and Schmidbauer (2014) for a full description of these parameters [77].

Horizontal movement estimates were made using the deployment location and the first satellite transmission location. Tag depth records paired with bathymetric depth of the study area were used to assist general movement directions and conservative (straight line from $\mathrm{A}$ to $\mathrm{B}$ ) distances travelled. Additionally, in periods of limited vertical movement, variability in recorded temperature data was assumed to represent horizontal movement.

Classifying benthos vs non-benthos positioning was determined using vertical movement plots. The lowest points in the vertical distribution were deemed to be benthos and those that were greater than $3 \mathrm{~m}$ than the previous points were considered non-benthos.

\section{Acknowledgements}

Many thanks to the crew of the Bluefin and the volunteers for their assistance, in particular Lachlan Fetterplace and Craig O'Connell.

\section{Authors' contributions}

PJB wrote the manuscript and created figures, PJB and JM analysed the data, JEW and JM participated in the at-sea operations, JEW designed the study, all authors contributed to writing, revising and approving the final manuscript. All authors read and approved the final manuscript.

\section{Funding}

Research was funded by the Department of Biological Sciences at Macquarie University, University of Newcastle and the Discovery Channel ${ }^{\mathrm{TM}}$. Patrick Burke and Jane Williamson received funding from a Save Our Seas Foundation Keystone Grant on sawsharks (2019/441).

\section{Availability of data and materials}

The datasets used and/or analysed during the current study are available from the corresponding author on reasonable request.

\section{Ethics approval and consent to participate}

Research was conducted under the approval of the Macquarie University Animal Ethics Committee, approval number ARA 2017_060 and the University of Tasmania Animal Ethics Committee, approval number A0015366, in collaboration with the University of Newcastle.

\section{Consent for publication}

Not applicable.

\section{Competing interests}

The authors declare that they have no competing interests.

\section{Author details}

${ }^{1}$ Department of Biological Sciences, Macquarie University, Sydney, NSW 2109, Australia. ${ }^{2}$ MARBEC, Univ Montpellier, CNRS, IFREMER, Sète, IRD, France. ${ }^{3}$ School of Environmental and Life Sciences, University of Newcastle, Ourimbah, NSW 2258, Australia. ${ }^{4}$ Sydney Institute of Marine Science, Mosman, NSW 2088, Australia.

Received: 25 May 2020 Accepted: 5 November 2020

Published online: 17 November 2020 


\section{References}

1. Brooks EJ, Brooks AML, Williams S, Jordan LKB, Abercrombie D, Chapman $D D$, et al. First description of deep-water elasmobranch assemblages in the Exuma Sound, The Bahamas. Deep Res Part II Top Stud Oceanogr. 2015:115(1):81-91.

2. Norse EA, Brooke S, Cheung WWL, Clark MR, Ekeland I, Froese R, et al. Sustainability of deep-sea fisheries. Mar Policy. 2012;36(2):307-20.

3. Georgeson L, Rigby CL, Emery TJ, Fuller M, Hartog J, Williams AJ, et al. Ecological risks of demersal fishing on deepwater chondrichthyan populations in the Southern Indian and South Pacific Oceans. ICES J Mar Sci. 2020.

4. Kyne PM, Simpfendorfer CA. Deepwater Chondrichthyans. In: Carrier JC, Musick JA, Heithaus MR, editors. Sharks and Their Relatives II:Biodiversity, adaptive physiology, and conservation. Boca Raton: CRC Press; 2010. p. 37-113.

5. White WT, Kyne PM. The status of chondrichthyan conservation in the Indo-Australasian region. J Fish Biol. 2010;76(9):2090-117.

6. Graham KJ, Daley RK. Distribution, reproduction and population structure of three gulper sharks (Centrophorus, Centrophoridae) in south-east Australian waters. Mar Freshw Res. 2011:436-9.

7. Hammerschlag N, Gallagher AJ, Lazarre DM. A review of shark satellite tagging studies. J Exp Mar Bio Ecol. 2011;398(1-2):1-8.

8. Knip DM, Heupel MR, Simpfendorfer CA. Sharks in nearshore environments: models, importance, and consequences. Mar Ecol Prog Ser. 2010:402:1-11.

9. Speed CW, Field IC, Meekan MG, Bradshaw CJ a. Complexities of coastal shark movements and their implications for management. Mar Ecol Prog Ser. 2010;408:275-93.

10. Sergio F, Newton I, Marchesi L, Pedrini P. Ecologically justified charisma : preservation of top predators delivers biodiversity conservation. J Appl Ecol. 2006;43.

11. Bascompte J, Melia CJ, Sala E. Interaction strength combinations and the overfishing of a Marine Food Web. Proc Natl Acad Sci. 2005;102(15):5443-7.

12. Schlaff AM, Heupel MR, Simpfendorfer CA. Influence of environmental factors on shark and ray movement, behaviour and habitat use: a review. Rev Fish Biol Fish. 2014;24(4):1089-103.

13. Cossaboon JM, Hoh E, Chivers SJ, Weller DW, Danil K, Maruya KA, et al. Apex marine predators and ocean health: proactive screening of halogenated organic contaminants reveals ecosystem indicator species. Chemosphere. 2019;221:656-64.

14. Wirsing A, Heithaus M, Dill L. Living on the edge: dugongs prefer to forage in microhabitats that allow escape from rather than avoidance of predators. Anim Behav. 2007;74(1):93-101.

15. Miles WTS, Parsons M, Close AJ, Luxmoore R, Furness RW. Predator-avoidance behaviour in a nocturnal petrel exposed to a novel predator. Ibis (Lond 1859). 2013;155(1):16-31.

16. Creel $S$, Christianson D. Relationships between direct predation and risk effects. Trends Ecol Evol. 2008;23:194-201.

17. Nevatte RJ, Williamson JE. The sawshark redemption: current knowledge and future directions for sawsharks (Pristiophoridae). Fish Fish 2020;00:1-25.

18. Raoult V, Peddemors V, Williamson JE. Biology of angel sharks (Squatina sp.) and sawsharks (Pristiophorus sp.) caught in south-eastern Australian trawl fisheries and the New South Wales shark-meshing (bather-protection) program. Mar Freshw Res. 2017;68(2):207-12.

19. Raoult V, Peddemors V, Rowling K, Williamson JE. Spatiotemporal distributions of two sympatric sawsharks (Pristiophorus cirratus and P. nudipinnis) in south-eastern Australian waters. Mar Freshw Res. 2020;71:1342-54.

20. Walker TI. Pristiophorus nudipinnis. IUCN Red List Threat Species. 2016.

21. Walker TI. Pristiophorus cirratus. IUCN Red List Threat Species. 2016;.

22. Patterson H, Williams A, Curtotti R. Fishery status reports 2019. Canberra; 2019.

23. Pennino MG, Conesa D, Lopez-Quilez A, Munoz F, Fernandez A, Bellido JM. Fishery-dependent and independent data lead to consistent estimations of essential habitats. ICES J Mar Sci. 2016:73:0-7.

24. Lascelles B, Notarbartolo G, Sciara D, Agardy T, Cuttelod A, Eckert $S$, et al. Migratory marine species: their status, threats and conservation management needs. Aquat Conserv Mar Freshw Ecosyst. 2014:24:111-27.
25. Last PR, Stevens J. Sharks and Rays of Australia. Second. Melbourne: CSIRO Publishing; 2009

26. Raoult V, Gaston TF, Williamson JE. Not all sawsharks are equal: species of co-existing sawsharks show plasticity in trophic consumption both within and between species. Can J Fish Aquat Sci. 2015:72(11):1769-75.

27. Burke PJ, Raoult V, Natanson LJ, Murphy TD, Peddemors V, Williamson JE. Struggling with age: Common sawsharks (Pristiophorus cirratus) defy age determination using a range of traditional methods. Fish Res [Internet]. 2020;231:105706. http://www.sciencedirect.com/science/ article/pii/S016578362030223X.

28. Nevatte RJ, Williamson JE, Vella NGF, Raoult V, Wueringer BE. Morphometry and microanatomy of the barbels of the common sawshark Pristiophorus cirratus (Pristiophoridae): implications for pristiophorid behaviour. J Fish Biol. 2017:90(5):1906-25.

29. Nevatte RJ, Wueringer BE, Jacob DE, Park JM, Williamson JE. First insights into the function of the sawshark rostrum through examination of rostral tooth microwear. J Fish Biol. 2017;91(6):1582-602.

30. Byrne ME, Cortés E, Vaudo JJ, Harvey GCMN, Sampson M, Wetherbee $\mathrm{BM}$, et al. Satellite telemetry reveals higher fishing mortality rates than previously estimated, suggesting overfishing of an apex marine predator. Proc R Soc B Biol Sci. 2017;284(1860).

31. Hays GC, Ferreira LC, Sequeira AMM, Meekan MG, Duarte CM, Bailey H, et al. Key Questions in Marine Megafauna Movement Ecology. Trends Ecol Evol. 2016;31(6):463-75

32. Commission for the Conservation of Antarctic Marine Living Resources Rep Twenty-Eighth Meet Sci Committee, CCAMLR. 2009.

33. Worm B, Barbier EB, Beaumont N, Duffy JE, Folke C, Halpern BS, et al. Impacts of Biodiversity Loss on Ocean Ecosystem Services. Science (80). 2006;314(5800):787-90.

34. Halpern BS, Walbridge S, Selkoe KA, Kappel C V., Micheli F, D'Agrosa C, et al. A global map of human impact on marine ecosystems. Science (80-). 2008;319(5865):948-52.

35. Worm B, Davis B, Kettemer L, Ward-Paige CA, Chapman D, Heithaus $M R$, et al. Global catches, exploitation rates, and rebuilding options for sharks. Mar Policy. 2013:40:194-204.

36. Garcia SM, Kolding J, Rice J, Rochet M-J, Zhou S, Arimoto T, et al. Reconsidering the Consequences of Selective Fisheries. Science (80-). 2012:335(6072):1045-7.

37. Worm B, Barbier EB, Beaumont N, Duffy JE, Folke C, Halpern BS, et al. Impacts of biodiversity loss on ocean ecosystem services. Science. 2006;314(5800):787-90.

38. Jackson JBC, Donovan MK, Cramer KL, Lam V, Lam W. Status and Trends of Caribbean Coral Reefs: 1970-2012. Glob Coral Reef Monit Network: IUCN, Gland Switz; 2014. p. 306.

39. Neumann T. Climate-change effects on the Baltic Sea ecosystem: a model study. J Mar Syst. 2010;81:213-24.

40. Ugochukwu CNC, Ertel J. Negative impacts of oil exploration on biodiversity management in the Niger De area of Nigeria. Impact Assess Pro Apprais. 2008:26(2):139-47.

41. Shipley ON, Howey LA, Tolentino ER, Jordan LKB, Brooks EJ. Novel techniques and insights into the deployment of pop-up satellite archival tags on a small-bodied deep-water chondrichthyan. Deep Res Part I Oceanogr Res Pap. 2016:2017(119):81-90.

42. Hammerschlag N, Gallagher AJ, Lazarre DM. A review of shark satellite tagging studies. J Exp Mar Bio Ecol [Internet]. 2011;398(1-2):1-8. Available from: http://dx.doi.org/10.1016/j.jembe.2010.12.012.

43. O'Neill R, Ó Maoiléidigh N, McGinnity P, Bond N, Culloty S. The novel use of pop-off satellite tags (PSATs) to investigate the migratory behaviour of European sea bass Dicentrarchus labrax. J Fish Biol. 2018:92(5):1404-21.

44. Rodríguez-cabello C, Sánchez F. Is Centrophorus squamosus a highly migratory deep-water shark? Deep Res Part. 2014;92:1-10.

45. McLaughlin RH, O'Gower AK. Life History and Underwater Studies of a Heterodont Shark. Ecol Monogr. 1971;41(4):271-89.

46. O'Gower AK, Nash AR. Dispersion of the Port Jackson shark in Australian waters. Sens Biol Sharks, Skates, Rays'(Eds ES Hodgson RF Mathewson) pp. 1978;529-44.

47. Bass NC, Mourier J, Knott NA, Day J, Guttridge T, Brown C. Long-term migration patterns and bisexual philopatry in a benthic shark species. Mar Freshw Res. 2017;68(8):1414-21. 
48. Sims DW, Wearmouth VJ, Southall EJ, Hill JM, Moore P, Rawlinson K, et al. Hunt warm, rest cool: bioenergetic strategy underlying diel vertical migration of a benthic shark. J Anim Ecol. 2005;75(1):176-90.

49. Spaet JLY, Lam CH, Braun CD, Berumen ML. Extensive use of mesopelagic waters by a Scalloped hammerhead shark (Sphyrna lewini) in the Red Sea. Anim Biotelemetry. 2017;1-12.

50. Afonso AS, Hazin FH V. Vertical movement patterns and ontogenetic niche expansion in the tiger shark, Galeocerdo cuvier. PLoS One [Internet]. 2015 Jan [cited 2015 Mar 27];10(1):e0116720. http://www. pubmedcentral.nih.gov/articlerender.fcgi?artid=4309595\&tool=pmcen trez\&rendertype $=$ abstract.

51. Sepulveda CA, Heberer C, Aalbers SA, Spear N, Kinney M, Bernal D, et al. Post-release survivorship studies on common thresher sharks (Alopias vulpinus) captured in the southern California recreational fishery. Fish Res. 2015;161:102-8.

52. Andrzejaczek S, Gleiss AC, Pattiaratchi CB, Meekan MG. Patterns and drivers of vertical movements of the large fishes of the epipelagic. Rev Fish Biol Fish. 2019;1.

53. Carey FG, Scharold JV. Movements of blue sharks (Prionace glauca) in depth and course. Mar Biol. 1990;106:329-42.

54. Rogers CN, Williamson JE, Carson DG, Steinberg PD. Diel vertical movement by mesograzers on seaweeds. Mar Ecol Prog Ser. 1998;

55. Comfort CM, Weng KC. Vertical habitat and behaviour of the bluntnose sixgill shark in Hawaii. Deep Res Part II Top Stud Oceanogr. 2015;115:116-26.

56. Weng KC, Block BA. Diel vertical migration of the bigeye thresher shark (Alopias superciliosus), a species possessing orbital retia mirabilia. Fish Bull. 2004;102(1):221-9.

57. Nakano $\mathrm{H}$, Matsunaga $\mathrm{H}$, Okamoto $\mathrm{H}$, Okazaki M. Acoustic tracking of bigeye thresher shark Alopias superciliosus in the eastern Pacific Ocean. Mar Ecol Prog Ser. 2003;265:255-61.

58. Barnett A, Abrantes KG, Stevens JD, Bruce BD, Semmens JM. Fine-Scale Movements of the Broadnose Sevengill Shark and Its Main Prey, the Gummy Shark. PLoS One. 2010;5(12).

59. Nelson DR, Wesley R. Strong J, Lowe CG, Sisneros JA, Schroeder DM, Lavenberg RJ. An acoustic tracking of a megamouth shark, Megachasma pelagios: a crepuscular vertical migrator. Environ Biol Fishes. 1997;49:389-399.

60. Krumme U. Diel and Tidal Movements by Fish and Decapods Linking Tropical Coastal Ecosystems. In: Nagelkerken I, editor. Ecological Connectivity among Tropical Coastal Ecosystems. Dordrecht: Springer Netherlands; 2009. p. 271-324.

61. Reynolds WW, Casterlin ME. Diel Activity of the Pink Shrimp Penaeus duorarum. Hydrobiologia. 1979;66(3):223-6.

62. Pearcy WG, Brodeur RD. Nekton. In: Encyclopedia of Ocean Sciences (Second Edition). Elsevier B.V.; 2009. p. 1-7.

63. Scheuerell MD, Schindler DE. Diel Vertical Migration by Juvenile Sockeye Salmon: empirical Evidence for the Antipredation Window. Ecology. 2003;84(7):1713-20.

64. Gallagher AJ, Frick LH, Bushnell PG, Brill RW, Mandelman JW. Blood gas, oxygen saturation, ph, and lactate values in elasmobranch blood measured with a commercially available portable clinical analyzer and standard laboratory instruments. J Aquat Anim Health. 2010;22:229-34.

65. Cooke SJ, Suski CD, Danylchuk SE, Danylchuk AJ, Donaldson MR, Pullen C, et al. Effects of different capture techniques on the physiological condition of bonefish Albula vulpes evaluated using field diagnostic tools. J Fish Biol. 2008;73(6):1351-75.

66. Gallagher AJ, Serafy JE, Cooke SJ, Hammerschlag N. Physiological stress response, reflex impairment, and survival of five sympatric shark species following experimental capture and release. Mar Ecol Prog Ser. 2014;496:207-18.

67. Raoult V, Williamson JE, Smith TM, Gaston TF. Effects of on-deck holding conditions and air exposure on post-release behaviours of sharks revealed by a remote operated vehicle. J Exp Mar Bio Ecol. 2019;511:10-8.

68. Cooke SJ, Raby GD, Donaldson MR, Hinch SG, O' Connor CM, Arlinghaus $\mathrm{R}$, et al. The physiological consequences of catch-and- release angling: perspectives on experimental design, interpretation, extrapolation and relevance to stakeholders. Fish Manag Ecol. 2013;20:268-87.

69. Frick LH, Reina RD, Walker TI. Stress related physiological changes and post-release survival of Port Jackson sharks (Heterodontus portusjacksoni) and gummy sharks (Mustelus antarcticus) following gill-net and longline capture in captivity. J Exp Mar Bio Ecol. 2010;385(1-2):29-37.

70. Brooks EJ, Sloman KA, Liss S, Hassan-Hassanein L, Danylchuk AJ, Cooke SJ, et al. The stress physiology of extended duration tonic immobility in the juvenile lemon shark, Negaprion brevirostris (Poey 1868). J Exp Mar Bio Ecol [Internet]. 2011;409(1-2):351-60. http://dx.doi.org/10.1016/j.jembe 2011.09.017.

71. Braccini M, Rijn J Van, Frick L. High Post-Capture Survival for Sharks, Rays and Chimaeras Discarded in the Main Shark Fishery of Australia? PLoS One. 2012;7(2).

72. Williams $\sqcup$, Herbig JL, Szedlmayer ST. A cage release method to improve fish tagging studies. Fish Res. 2015;172:125-9.

73. Papastamatiou YP, Meyer CG, Kosaki RK, Wallsgrove NJ, Popp BN. Movements and foraging of predators associated with mesophotic coral reefs and their potential for linking ecological habitats. Mar Ecol Prog Ser. 2015;521:155-70.

74. Harcourt R, Sequeira AMM, Zhang X, Roquet F, Komatsu K, Heupel M, et al. Animal-Borne Telemetry: An Integral Component of the Ocean Observing Toolkit. Front Mar Sci [Internet]. 2019;6(June). https://www. frontiersin.org/article/10.3389/fmars.2019.00326/full.

75. Cazelles B, Chavez M, Berteaux D, Menard F, Vik JO, Jenouvrier S, et al. Wavelet analysis of ecological time series. Oecologia. 2008;156:287-304

76. Percival DB, Walden AT. Wavelet Methods for Time Series Analysis. Cambridge University Press; 2000.

77. Roesch A, Schmidbauer H. WaveletComp: computational wavelet analysis. R Packag version. 2014;1.

\section{Publisher's Note}

Springer Nature remains neutral with regard to jurisdictional claims in published maps and institutional affiliations.

\footnotetext{
Ready to submit your research? Choose BMC and benefit from:

- fast, convenient online submission

- thorough peer review by experienced researchers in your field

- rapid publication on acceptance

- support for research data, including large and complex data types

- gold Open Access which fosters wider collaboration and increased citations

- maximum visibility for your research: over 100M website views per year
}

At $\mathrm{BMC}$, research is always in progress.

Learn more biomedcentral.com/submissions 